\title{
Protective Effects of N-Acetyl Cysteine against Paclitaxel-Induced Cardiotoxicity Through Modulation of Transient Receptor Potential Melastatin 2 Channels
}

\author{
Geçici Reseptör Potansiyel Melastatin 2 Kanallarının Modülasyonu ile N-Asetil Sisteinin Paklitaksel Nedenli \\ Kardiyotoksisiteye Karşı Koruyucu Etkileri
}

\section{Can Ramazan Öncel ${ }^{1}$, Ishak Suat Ovey ${ }^{2}$}

${ }^{1}$ Alanya Alaaddin Keykubat University, Faculty of Medicine, Department of Cardiology, Antalya, Turkey

${ }^{2}$ Alanya Alaaddin Keykubat University, Faculty of Medicine, Department of Physiology, Antalya, Turkey

\section{ABSTRACT}

Aim : In our study, we investigated the paclitaxel induced cardiotoxicity and alterations in $\mathrm{Ca} 2+$ influx, oxidative stress and apoptosis through transient receptor potential melastatin 2 (TRPM2) channels and modulator role of $\mathrm{N}$ acetyl cysteine (NAC) in cardiomyocytes.

Material and Methods : All cells were cultured at $37^{\circ} \mathrm{C}$. The cells were divided into seven main groups. Cells in the paclitaxel group were incubated with 2.5 $\mu \mathrm{M}$ Paclitaxel for 12 hours and cells in the NAC+Paclitaxel group were incubated with $2.5 \mu \mathrm{M}$ Paclitaxel for 12 hours and then incubated with $10 \mu \mathrm{M}$ NAC for 24 hours. Intracellular free calcium concentration, reactive oxygen species (ROS) production measurements and cell viability analyses were done according to the study protocol.

Results : Cytosolic calcium levels, apoptosis levels, intracellular ROS production levels were lower in paclitaxel+NAC group than in the paclitaxel group of cardiomyocytes. Also values were markedly lower in the paclitaxel+NAC+antranilic acid group when compared to the paclitaxel+NAC group.

Conclusion : We found that TRPM2 channels are overactivated during paclitaxel induced cardiotoxicity and NAC could show a cardioprotective effect through TRPM2 channel modulation.

Key Words: Apoptosis, paclitaxel, cardiomyocyte, transient receptor potential melastatin 2, N-acetyl cysteine

Received: 05.24 .2018

\section{ÖZET}

Amaç: Biz çalışmamızda paklitaksel kaynaklı kardiotoksisiteyi ve kardiyomiyositlerde transient reseptör potansiyel melastatin 2 (TRPM2) kanalları üzerinden $\mathrm{Ca}+2$ akışı, oksidatif stres ve apoptoz değerlerindeki değişimleri ve $\mathrm{N}$-asetil sistein (NAC) 'in modülator rolünü araştırdık.

Materyal ve Method: Bütün hücreler $37^{\circ} \mathrm{C}$ ' de kültürlendi. Hücreler yedi ana gruba ayrıldı. Paklitaksel grubundaki hücreler, 12 saat boyunca $2.5 \mu \mathrm{M}$ Paklitaksel ile inkübe edildi ve NAC+Paklitaksel grubundaki hücreler, 12 saat boyunca $2.5 \mu \mathrm{M}$ Paklitaksel ile inkübe edildi ve daha sonra 24 saat boyunca 10 $\mu \mathrm{M}$ NAC ile inkübe edildi. Çalışma protokolüne göre intraselüler serbest kalsiyum konsantrasyonu, reaktif oksijen türleri (ROS) üretim ölçümleri ve hücre canlılığı analizleri yapıldı.

Bulgular : Kardiyomiyositlerdeki sitosolik kalsiyum seviyeleri, apoptoz seviyeleri, hücre içi ROS üretim seviyeleri; paklitaksel+NAC grubunda, paklitaksel grubuna göre daha düşüktü. Ayrıca paklitaksel+NAC grubu ile karşılaştırıldığında paklitaksel+NAC+antranilik asit grubunda da belirgin olarak daha düşük değerler elde edildi.

Sonuç : TRPM2 kanallarının paklitaksel kaynaklı kardiyotoksisite sırasında aşırı aktif olduğunu ve NAC'in TRPM2 kanal modülasyonu ile kardiyoprotektif etki gösterebileceğini bulduk.

Anahtar Sözcükler : Apoptoz, paklitaksel, kardiyomiyosit, transient reseptör potansiyel melastatin $2, \mathrm{~N}$-asetil sistein

Geliş Tarihi: 24.05.2018 


\section{INTRODUCTION}

Cardiotoxicity is a potential complication of chemotherapy, and it can limit the clinical use of chemotherapeutic agents. These agents induce apoptosis and necrosis and lead to the suppression of angiogenesis or deterioration of repair mechanisms not only in cancer cells but also in cardiomyocytes. The generation of oxidative stress is a widely accepted pathophysiological mechanism underlying chemotherapy-induced cardiomyopathy $(1,2)$. Paclitaxel (PAC), an inhibitor of microtubule polymerization, is widely used as a treatment for multiple malignancies (3). The incidence of left ventricular dysfunction associated with PAC ranges from 5 to 15\% (4). The underlying pathophysiological mechanism associated with PAC-induced cardiotoxicity is not well understood. According to some research, PAC can induce cardiac muscle damage by affecting subcellular organelles (5). Other research reported that PAC altered cytosolic calcium $\left(\mathrm{Ca}^{2+}\right)$ signaling by affecting mitochondrial permeability (6).

As the management of adverse cardiovascular events in patients treated with PAC is not well defined, it is important to understand the molecular mechanisms. Meshkini et al. reported that PAC-induced cytotoxicity was associated with the generation of reactive oxygen species (ROS) and glutathione depletion (7). At present, there is no reliable and effective preventative treatment for PAC-induced cytotoxicity.

We speculated that antioxidants could be used for cardioprotection. The present study focused on the potent antioxidant $\mathrm{N}$-acetyl cysteine (NAC), which is a widely used drug in clinical practice. Previous studies demonstrated that NAC provided protection against drug-induced cardiac damage $(8,9)$. The mechanisms of NAC and its effects on cardiotoxicity are related to its antioxidant activity, effects on mitochondrial function, and regulation of cell survival and apoptosis (10).

Transient receptor potential (TRP) channels are unique ion channels, which influence cell apoptosis and survival. TRP melastatin 2 (TRPM2), a member of the melastatin TRP family, is widely expressed in many cell types, including cardiac cells. It is activated in response to oxidative stress, which can be initiated by pharmacological stimuli $(11,12)$. TRPM2 channels are permeable to $\mathrm{Ca}^{2+}$ and have been investigated in several conditions associated with oxidative stress. Thus, the activation of these channels may play a major role in the pathogenesis of chemotherapy-induced cardiotoxicity.

Previous research demonstrated the role of TRPM2 channels and the protective effects of NAC against oxidative stress and $\mathrm{Ca}^{2+}$ influx in other cell types (13). The aim of the present study was to investigate the effect of PAC therapy on $\mathrm{Ca}^{2+}$ signaling, apoptosis, and oxidative stress in cardiomyocytes and to evaluate the cardioprotective effect of NAC through TRPM2 channels at the cellular level in an in vitro model.

\section{MATERIAL and METHODS}

\section{Cell culture and reagents}

A human cardiomyocyte cell line, (AC16), was purchased from ATCC. The cardiomyocytes were cultured in Dulbecco's modified Eagle's medium (DMEM) (Sigma) containing 10\% fetal bovine serum (Fisher Scientific) and 1\% penicillin/streptomycin (Thermo Fisher, MA, USA). The cells were evenly distributed $\left(1 \times 10^{6}\right.$ cells) in each of 8-10 sterile filter cap flasks $\left(5 \mathrm{ml}, 25 \mathrm{~cm}^{2}\right)$. The cells were then incubated at $37^{\circ} \mathrm{C}$ in a $5 \%$ carbon dioxide incubator in a humidified atmosphere. After the cells reached $75-85 \%$ confluence, they were incubated with the chemical compounds described in the groups section. The cells were examined daily for evidence of contamination. After the treatments, the cells were detached using $0.25 \%$ Trypsin/EDTA and split into sterile Falcon tubes for analyses. All the cells in the study groups were obtained from the same passage.

APOPercentage dye with releasing buffer were purchased from Biocolor Ltd. (Northern Ireland), JC1 was purchased from Santa Cruz (TX, USA), and Fura 2 AM was purchased from Calbiochem (Darmstadt, Germany). For the 3-(4,5dimethylthiazol-2-yl)-2,5-diphenyltetrazolium bromide (MTT) cell viability assay, MTT dye was purchased from Thermo Fisher. Dihydrorhodamine-123 (DHR123) was obtained from Molecular Probes (OR, USA). Caspase 3 and caspase 9 substrates were purchased from Biovision (CA, USA).

\section{Groups}

The study was planned as 7 main groups below and all the cells in the study groups were obtained from the same passage.

Group 1 (Control): None of the study drugs were used and cardiomyocytes were kept in a flask containing the same cell culture condition.

Group 2 (PAC): Cardiomyocytes were incubated with $2.5 \mu \mathrm{M}$ paclitaxel for 12 hrs (14).
Group 3 (PAC+ACA): Cardiomyocytes were incubated with $2.5 \mu \mathrm{M}$ paclitaxe for $12 \mathrm{hrs}$ and then incubated with antranilic acid (ACA, $0.04 \mathrm{mM}, 30 \mathrm{~min}$ ). Group 4 (PAC+NAC): Cardiomyocytes were incubated with $2.5 \mu \mathrm{M}$ paclitaxel for $12 \mathrm{hrs}$ and then incubated with $10 \mu \mathrm{M} \mathrm{N}$-acetyl cysteine for $24 \mathrm{hrs}$. Group 5 (PAC+NAC+ACA): Cardiomyocytes were incubated with $2.5 \mu \mathrm{M}$ paclitaxel for $12 \mathrm{hrs}$ and then incubated with $10 \mu \mathrm{M} \mathrm{N}$-acetyl cysteine for 24 hrs and then incubated with antranilic acid (ACA, $0.04 \mathrm{mM}, 30 \mathrm{~min}$ ).

Group 6 (NAC): Cardiomyocytes were incubated with $10 \mu \mathrm{M} \mathrm{N}$-acetyl cysteine for $24 \mathrm{hrs}$ (15).

Group 7 (NAC+ACA): Cardiomyocytes were incubated with $10 \mu \mathrm{M} N$-acetyl cysteine for $24 \mathrm{hrs}$ and then incubated with antranilic acid (ACA, $0.04 \mathrm{mM}, 30$ $\mathrm{min})$.

In related experiments (except for calcium signaling), the cells were further treated with cumen hydroperoxide (CMPx) $(0.1 \mathrm{mM}, 10 \mathrm{~min})$ and during calcium signaling analysis (Fura $2 \mathrm{AM}$ ), cells were stimulated on $20^{\text {th }}$ cycles with $0.1 \mathrm{mM}$ CMPx for activation of TRPM2 channel before related analysis in the existence of normal calcium $(1.2 \mathrm{mM})$ in extracellular environment.

\section{Measurement of the intracellular $\mathrm{Ca}^{2+}\left(\mathrm{Ca}^{2+}{ }_{i}\right)$ concentration}

The $\mathrm{Ca}^{2+}{ }_{i}$ concentration was measured using ultraviolet light excitable Fura 2 acetoxymethyl ester dye (Calbiochem) as an intracellular free $\mathrm{Ca}^{2+}$ indicator. All the experimental procedures were carried out in accordance with those described by Uğuz et al. (16), which included $4 \mu \mathrm{M}$ Fura 2 AM (Calbiochem) fluorescent dye to staining period ending. The fluorescence emission intensity at $510 \mathrm{~nm}$ was determined in individual wells using a plate reader equipped with an automated injection system (Synergy ${ }^{\mathrm{TM}} \mathrm{H} 1$; Biotek, USA) at alternating excitation wavelengths of 340 and $380 \mathrm{~nm}$ every $3 \mathrm{~s}$ for 50 acquisition cycles. During the measurement of $\mathrm{Ca}^{2+}{ }_{i}$ signaling, the TRPM2 channels were stimulated using an automatic injector with cumene hydroperoxide (0.1 mM) on the 20th cycle. $\mathrm{Ca}^{2+}{ }_{i}$ was measured as modified by Uguz et al. and Martinez et al. $(16,17)$.

Measurement of the production of intracellular ROS

The measurement of intracellular ROS production was carried out in accordance with the experimental procedure of Espino et al. (18). The cells ( $10^{6}$ cells $/ \mathrm{ml}$ per group) were incubated with $20 \mu \mathrm{m}$ of a noncharged, nonfluorescent dye, DHR123, at $37^{\circ} \mathrm{C}$ for $25 \mathrm{~min}$ (18). The $\mathrm{DH} 123$ dye easily passes through the cell membrane and is oxidized to cationic rhodamine 123 (Rh 123) inside the cardiomyocytes. Rh 123 localizes in the mitochondria and exhibits green fluorescence. A Synergy ${ }^{\mathrm{TM}} \mathrm{H} 1$ (Biotek) automatic microplate reader device was used for determining the fluorescent intensities of Rh 123. The analyses were performed at $488 \mathrm{~nm}$ (excitation) and $543 \mathrm{~nm}$ (emission) wavelengths. The data are presented as the fold increase as compared with the level before the treatment.

\section{Apoptosis assay}

APOPercentage (Biocolor Ltd.) dye was used for the detection and quantification of apoptosis. The dye actively bound to phosphatidyl serine lipids and was transferred into the cells. The apoptotic cells were stained red. An apoptosis assay was performed according to the manufacturer's instruction and the method of Özdemir et al. (19). Apoptotic cells were detected using a microplate spectrophotometer at $550 \mathrm{~nm}$ (Synergy ${ }^{\mathrm{TM}} \mathrm{H1}$; Biotek).

\section{Caspase 3 and caspase 9 activity assays}

Caspase 3 and caspase 9 activity were measured using methods described previously $(20,21)$. Caspase 3 (AC-DEVD-AMC) and caspase 9 (AC-LEHD-AMC) substrates cleavages were determined using a Synergy ${ }^{\mathrm{TM}} \mathrm{H} 1$ (Biotek) microplate reader at $360 \mathrm{~nm}$ and $460 \mathrm{~nm}$ wavelengths (excitation/emission). The values were evaluated as fluorescent units/mg protein and shown as the fold increase over the level before treatment (experimental/control). Analysis of the mitochondrial membrane potential

The mitochondrial membrane potential was determined by assessing the fluorescence intensity of the JC1 $(1 \mu \mathrm{M})$ dye at a single excitation wavelength of $485 \mathrm{~nm}$ (green), emission wavelength of $535 \mathrm{~nm}$, and red signal at $540 \mathrm{~nm}$ (excitation) and $590 \mathrm{~nm}$ (emission) wavelengths (Synergy ${ }^{\mathrm{TM}} \mathrm{H} 1$; Biotek) (22, 23). Data are presented as emission ratios (590/535). Mitochondrial membrane potential changes were quantified as the integral of the decrease in the JC1 fluorescence ratio of the experimental/control.

\section{Cell viability (MTT) assay}

Cell viability was evaluated by an MTT assay. After treatment with the chemical compounds described in the group sections, the cardiomyocytes were washed and then incubated with fresh DMEM containing MTT 0.5 $\mathrm{mg} / \mathrm{ml}$ ) at $37^{\circ} \mathrm{C}$ for $90 \mathrm{~min}(24)$. The supernatants were then removed, and dimethyl-sulfoxide was added to dissolve the formazan crystals. 
The optical density was estimated using a Synergy ${ }^{\mathrm{TM}} \mathrm{H} 1$ (Biotek) automatic microplate reader at a test wavelength of $490 \mathrm{~nm}$ and a reference wavelength of $650 \mathrm{~nm}$ to nullify the effect of cell debris. The obtained data are shown as the fold increase over the level before the treatment (experimental/control). Statistical analysis

All data are presented as mean \pm standard deviation (SD). To compare the different treatments, statistical significance was calculated by a one-way analysis of variance and the Mann-Whitney $U$ test. All the data were analyzed using the SPSS statistical program, version 9.05 software (SPSS Inc., IL, USA). A value of $p<0.05$ was considered statistically significant.

\section{RESULTS}

Effects of PAC and NAC administrations on cytosolic calcium levels through TRPM2 channel activation in cardiomyocytes

The effect of PAC and NAC administrations on cytosolic calcium levels in cardiomyocyte cells are shown in figure 1A-B. The TRPM2 channel antagonist antranilic acid (ACA) was used to evaluate the receptors related to involvement of $\mathrm{Ca}^{2+}$ increase through TRPM2 channels. As shown in figure $1 \mathrm{~A}-$ $B$, the $\mathrm{Ca}^{2+}$ concentration in cardiomyocytes was $(p<0.001)$ higher in the PAC group than in the control. The $\mathrm{Ca}^{2+}$ concentration was lower in the NAC+ACA group compared to the control $(p<0.001)$. Also cytosolic $\mathrm{Ca}^{2+}$ concentration was lower in the PAC+ACA, PAC+NAC and PAC+NAC+ACA groups than in the $P A C$ group $(p<0.001)$.

In addition, cytosolic $\mathrm{Ca}^{2+}$ concentration in the cardiomyocytes was markedly lower in the PAC+NAC+ACA group compared to the PAC+NAC group $(p<0.001)$.

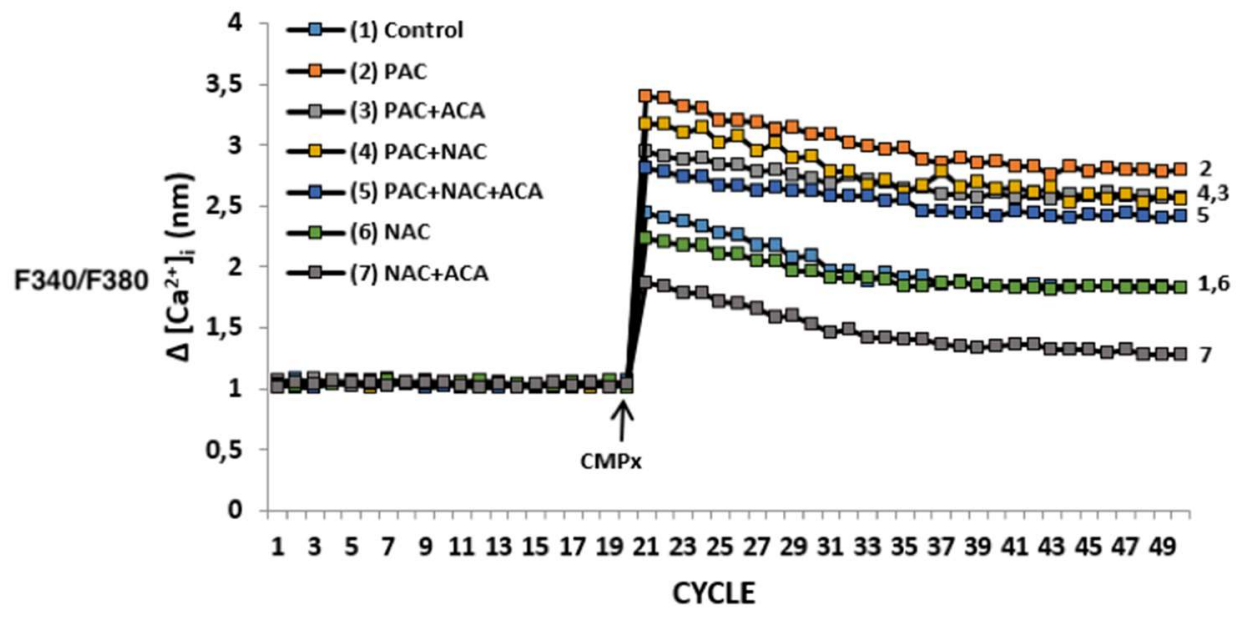

B

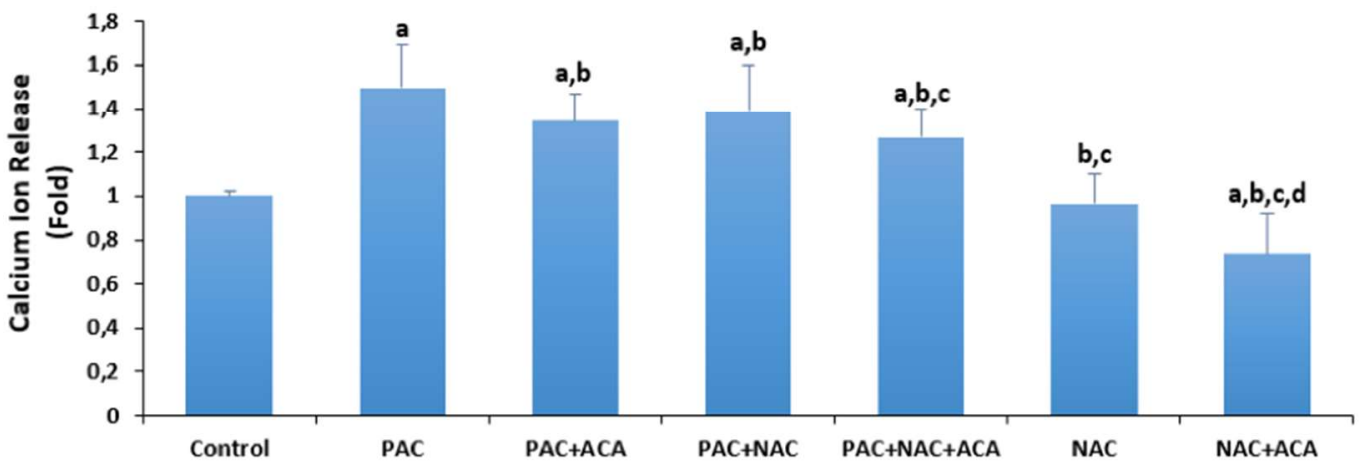

Figure 1A-B. The effect of paclitaxel (PAC) (2.5 micromolar, $12 \mathrm{hrs})$ and N-acetyl cysteine (NAC) $(10 \mu \mathrm{M}, 24 \mathrm{hrs})$ on the [Ca $\left.\mathrm{a}^{2+}\right]$ i concentration (A) and cytosolic calcium release (B) in cardiomyocyte cells. Cells are stimulated by cumene hydroperoxide (CMPx $0.1 \mathrm{mM}$ and on $20^{\text {th }} \mathrm{cycle}$ ) and cells in the antranilic acid groups (PAC+ACA, $P A C+N A C+A C A, N A C+A C A$ ) were inhibited with antranilic acid (ACA $0.04 \mathrm{mM}$ for $30 \mathrm{~min}$ ) (mean $\pm S D$ and $n=10$ ). ${ }^{a} p<0.001$ vs control, ${ }^{b} p<0.001$ vs $P A C,{ }^{c} p<0.001$ vs $P A C+N A C$ and ${ }^{d} p<0.001$ vs NAC

PAC: Paclitaxel group, PAC+ACA: Paclitaxel+antranilic acid group, PAC+NAC: Paclitaxel+N-acetyl cysteine group, PAC+NAC+ACA: Paclitaxel+N-acetyl cysteine+ antranilic acid group, NAC: $\mathrm{N}$-acetyl cysteine group, NAC+ACA: $\mathrm{N}$-acetyl cysteine+antranilic acid group

Effects of paclitaxel and NAC administrations on apoptosis levels in cardiomyocytes

Effects of paclitaxel and NAC administrations on apoptosis levels are shown in figure 2. The apoptosis values were significantly higher in the paclitaxel group than control. The apoptosis values were significantly lower in the NAC and the $P A C+N A C$ group than in the PAC group of cardiomyocytes $(p<0.001)$. Also the values were lower in the PAC+NAC+ACA group when compared with the PAC+NAC group of cardiomyocytes $(p<0.001)$. 


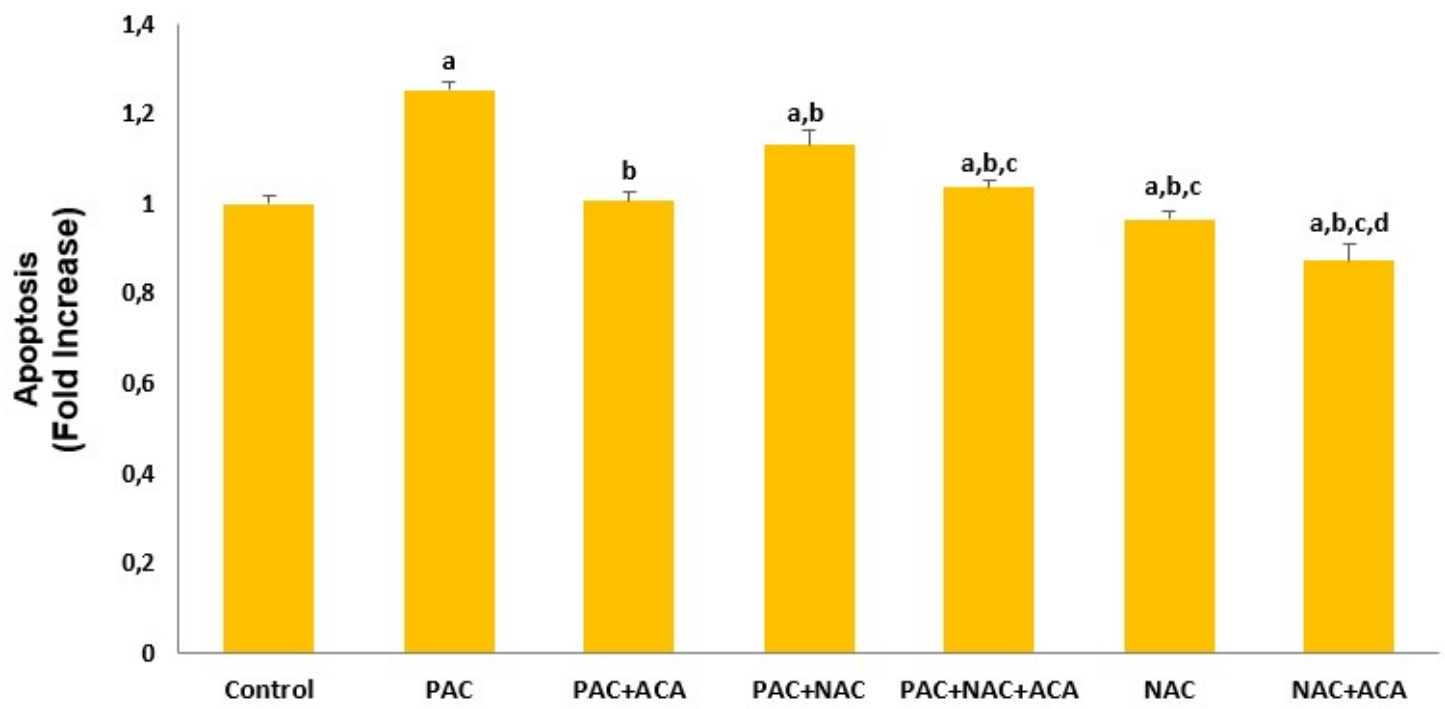

Figure 2. The effect of paclitaxel (PAC) ( 2.5 micromolar, $12 \mathrm{hrs})$ and $\mathrm{N}$-acetyl cysteine (NAC) (10 $\mu \mathrm{M}, 24 \mathrm{hrs})$ on apoptosis levels in the cardiomyocyte cells. Cells are stimulated by cumene hydroperoxide (CMPx $0.1 \mathrm{mM}$ for $10 \mathrm{~min}$ ) and cells in the antranilic acid groups (PAC+ACA, PAC+NAC+ACA, NAC+ACA) were inhibited with antranilic acid (ACA $0.04 \mathrm{mM}$ for $30 \mathrm{~min}$ ) (mean $\pm S D$ and $n=10)$. ${ }^{a} p<0.001$ vs control, ${ }^{b} p<0.001$ vs $P A C,{ }^{c} p<0.001$ vs PAC+NAC and ${ }^{d} p<0.001$ vs NAC.

PAC: Paclitaxel group, PAC+ACA: Paclitaxel+antranilic acid group, $\mathrm{PAC}+\mathrm{NAC}$ : Paclitaxel+N-acetyl cysteine group, $\mathrm{PAC}+\mathrm{NAC}+\mathrm{ACA}$ : Paclitaxel+N-acetyl cysteine+antranilic acid group, NAC: $\mathrm{N}$-acetyl cysteine group, NAC+ACA: $\mathrm{N}$-acetyl cysteine+antranilic acid group.

Effects of paclitaxel and NAC administrations on intracellular ROS production in cardiomyocytes

We show intracellular ROS production of groups in figure 3. Intracellular ROS levels were significantly higher in the paclitaxel group than control. The values were lower in the PAC+ACA $(p<0.001)$, the PAC+NAC $(p<0.001)$ and the $\mathrm{PAC}+\mathrm{NAC}+\mathrm{ACA}(\mathrm{p}<0.001)$ than in the PAC group. Also the ROS production was markedly lower in the PAC+NAC+ACA group when compared to the PAC+NAC $(p<0.001)$.

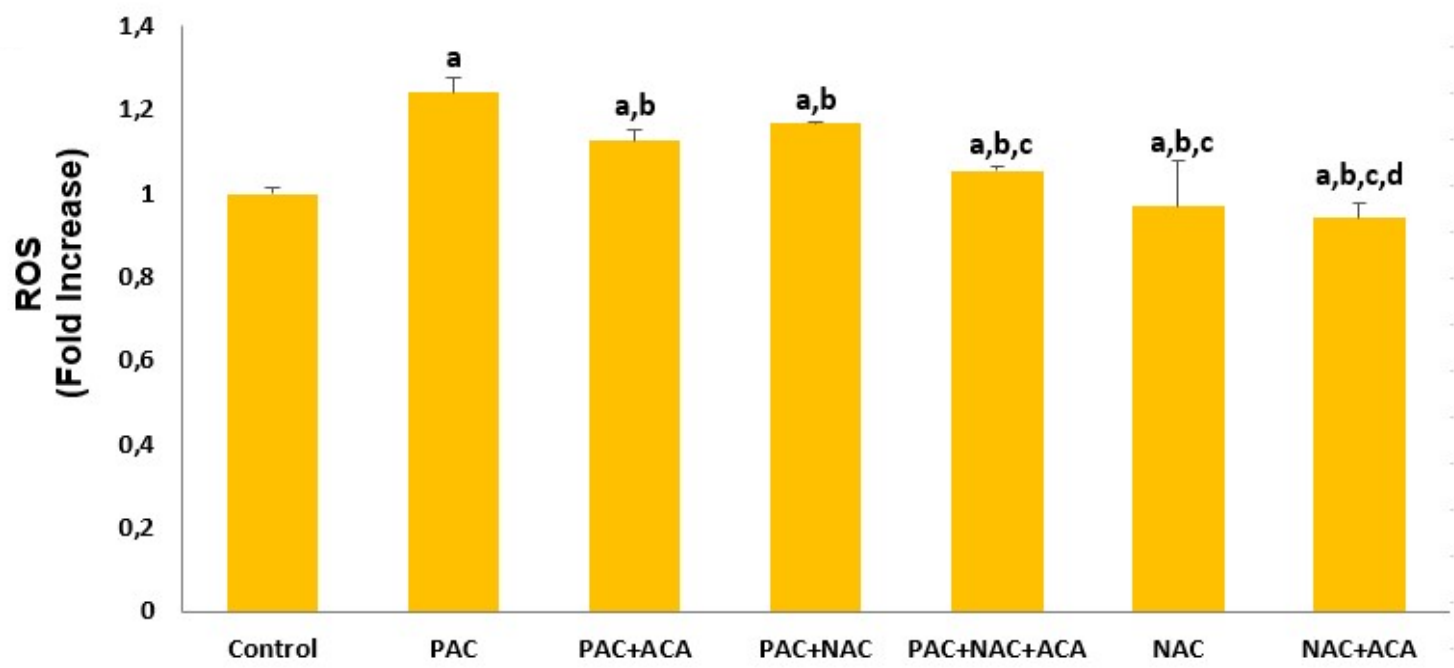

Figure 3. The effect of paclitaxel (PAC) ( 2.5 micromolar, $12 \mathrm{hrs}$ ) and $\mathrm{N}$-acetyl cysteine (NAC) (10 $\mu \mathrm{M}$, 24 hrs) on reactive oxygene species levels in the cardiomyocyte cells. Cells are stimulated by cumene hydroperoxide (CMPx $0.1 \mathrm{mM}$ for $10 \mathrm{~min}$ ) and cells in the antranilic acid groups (PAC+ACA, PAC+NAC+ACA, NAC+ACA) were inhibited with antranilic acid (ACA $0.04 \mathrm{mM}$ for $30 \mathrm{~min}$ ) (mean $\pm S D$ and $n=10$ ). ${ }^{a} p<0.001$ vs control, ${ }^{b} p<0.001$ vs $P A C,{ }^{c} p<0.001$ vs $P A C+N A C$ and ${ }^{d} p<0.001$ vs $N A C$. PAC: Paclitaxel group, PAC+ACA: Paclitaxel+antranilic acid group, PAC+NAC: Paclitaxel+N-acetyl cysteine group, PAC+NAC+ACA: Paclitaxel+N-acetyl cysteine+antranilic acid group, NAC: $\mathrm{N}$-acetyl cysteine group, NAC+ACA: $\mathrm{N}$-acetyl cysteine+antranilic acid group.

Effects of paclitaxel and NAC administrations on caspase 3 and 9 activities, mitochondrial depolarization levels and cell viability ( MTT) values in cardiomyocytes

Mitochondrial membrane depolarization levels, caspase 3 and caspase 9 activities and cell viability (MTT) values of groups are shown in figure 4 (A-B-
C-D) respectively. It has been shown that caspase 3 and 9 activities have an important role in the mitochondrial apoptotic pathways. Also they are associated with mitochondrial cytochrome c releasing during the apoptotic cascade. MTT values were significantly lower in the PAC group than control $(p<0.001)$. The values were significantly higher in the PAC+ACA $(p<0.001)$ and $P A C+N A C+A C A(p<0.001)$ groups than in the PAC group. 


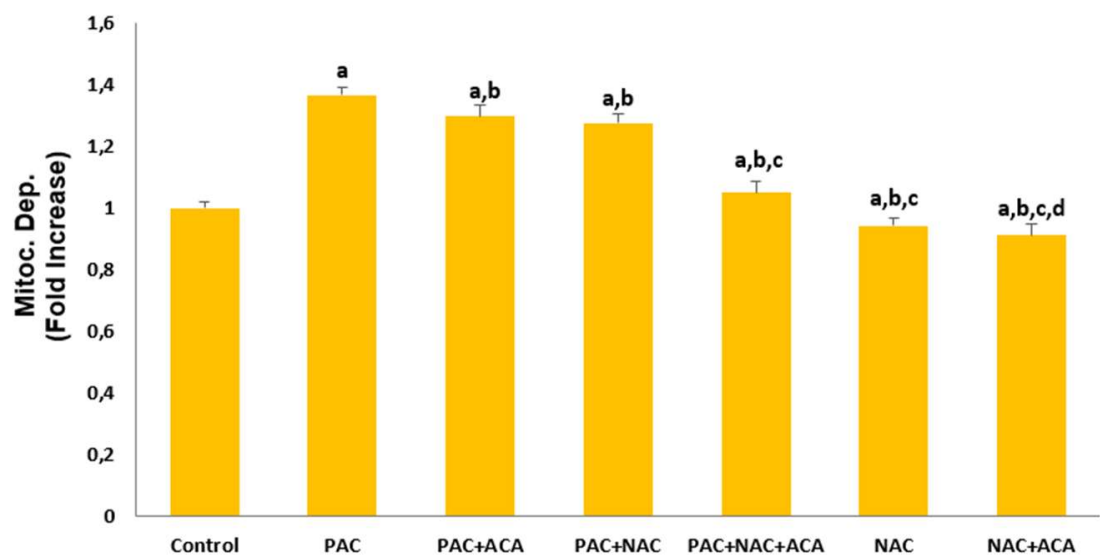

B
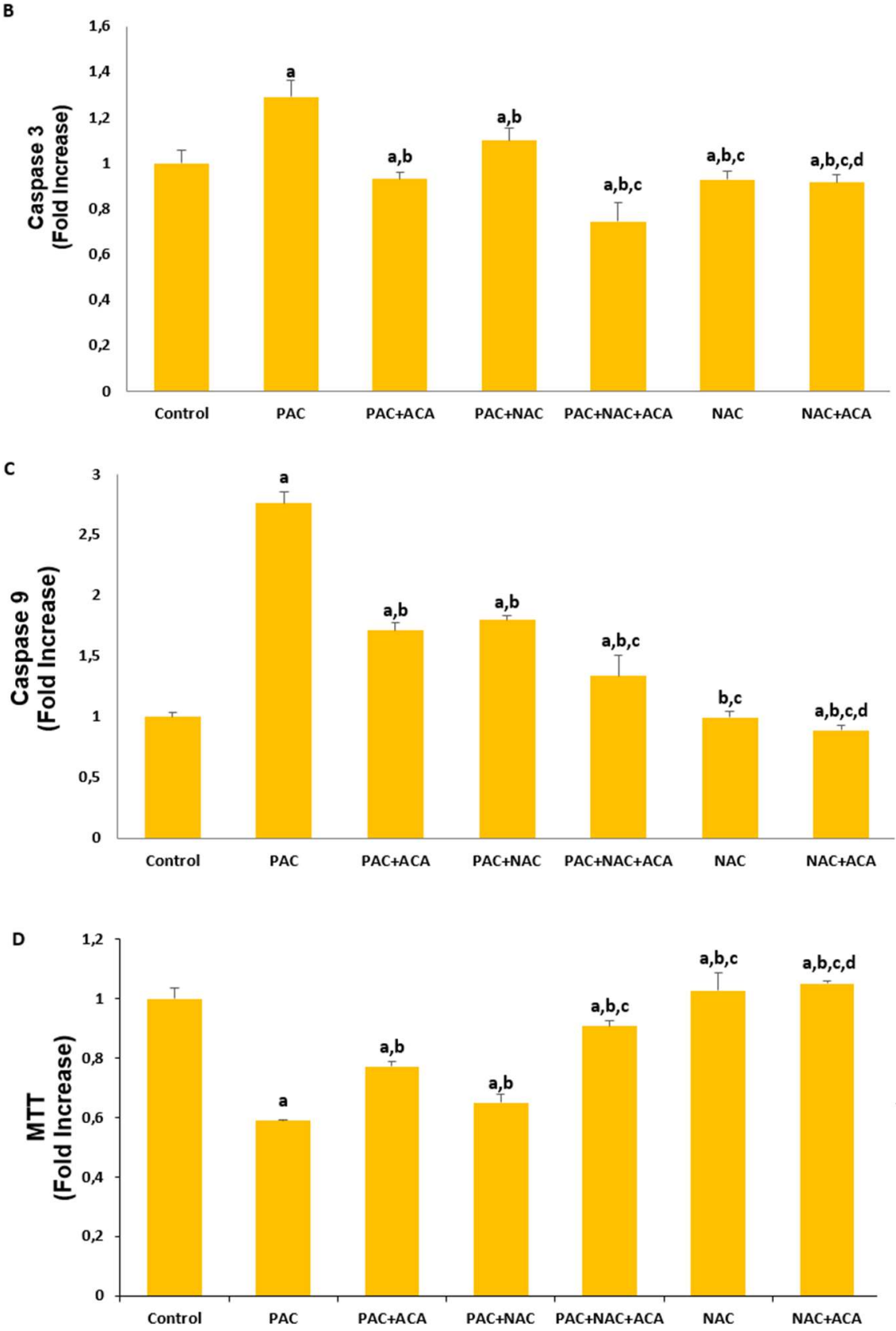

Figure 4A-D. The effect of paclitaxel (PAC) (2.5 micromolar, $12 \mathrm{hrs}$ ) and $\mathrm{N}$-acetyl cysteine (NAC) (10 $\mu \mathrm{M}, 24 \mathrm{hrs})$ on mitochondrial membrane depolarization (A), Caspase 3 (B), Caspase 9 (C) and MTT-Cell Viability (D) levels in the cardiomyocyte cells. Cells are stimulated by cumene hydroperoxide (CMPx $0.1 \mathrm{Mm}$, for $10 \mathrm{~min}$ ) and cells in the antranilic acid groups (PAC+ACA, PAC+NAC+ACA, NAC+ACA) were inhibited with antranilic acid (ACA $0.04 \mathrm{mM}$ for $30 \mathrm{~min}$ ) ( $\mathrm{mean} \pm \mathrm{SD}$ and $\mathrm{n}=10$ ). ap<0.001 vs control, ${ }^{b} p<0.001$ vs PAC, ${ }^{c} p<0.001$ vs $P A C+N A C$ and ${ }^{d} p<0.001$ vs NAC.

PAC: Paclitaxel group, PAC+ACA: Paclitaxel+antranilic acid group, $\mathrm{PAC}+\mathrm{NAC}$ : Paclitaxel+N-acetyl cysteine group, $\mathrm{PAC}+\mathrm{NAC}+\mathrm{ACA}$ : Paclitaxel+N-acetyl cysteine+antranilic acid group, NAC: $\mathrm{N}$-acetyl cysteine group, NAC+ACA: $\mathrm{N}$-acetyl cysteine+antranilic acid group. 
Paclitaxel, an antimitotic drug, is used for the treatment of breast, ovarian, and non small cell lung cancers (25). Previous research reported that taxanes, such as PAC, can cause early left ventricular dysfunction and heart failure within $2 \mathrm{~d}$ of onset of therapy (26). Reported adverse effects of this chemotherapeutic agent on the heart included cardiomyocyte death, which led to cardiomyopathy or cardiac arrhythmias. The clinical cardiotoxicity of PAC was reported to range from 5-30\% (25), and co-administration of PAC and doxorubicin increased the incidence of congestive heart failure to $20 \%$ (27).

Despite the aforementioned data on PAC, the molecular mechanism of PACinduced cardiotoxicity remains unclear. Some studies suggested that both ROS and oxidative stress seemed to play a crucial role in chemotherapy-induced cardiotoxicity and subsequent cardiac dysfunction $(28,29)$. Studies also reported that widely used anticancer drugs, including PAC, induced mitochondrial dysfunction in vivo and in vitro $(30,31)$.

Mitochondria play an important role in cell survival and apoptosis. Santulli et al. reported that $\mathrm{Ca}^{2+}{ }_{i}$ overload was associated with mitochondrial dysfunction and impaired cardiac function after a myocardial infarction (32). Research showed that $\mathrm{Ca}^{2+}$ homeostasis was essential for the cellular physiology and pathophysiology in mitochondria, with mitochondrial $\mathrm{Ca}^{2+}$ uptake controlling $\mathrm{Ca}^{2+}{ }_{i}$ signals and having a major impact on cell death (33, 34). High levels of $\mathrm{Ca}^{+2}$ stimulated respiratory chain activity and were associated with increased levels of ROS (35). In a study by Kidd et al., PAC affected cytosolic $\mathrm{Ca}^{2+}$ signals by opening mitochondrial permeability transition pores (36). They concluded that the side effects of PAC could be associated with mitochondrial dysfunction and $\mathrm{Ca}^{2+}$ signal cascades (36). Pan et al. demonstrated that PAC-induced changes in $\mathrm{Ca}^{2+}$ significantly promoted apoptosis in breast cancer cells (14). Previous studies also demonstrated that $\mathrm{Ca}^{2+}$ was a major intracellular messenger and that it played an essential role in cardiomyocyte homeostasis and survival. Elevated levels of cytosolic $\mathrm{Ca}^{2+}$ stimulated ROS and led to the release of proapoptotic factors, which caused apoptosis $(37,38)$.

TRP channels belong to a family of plasma membrane transporters of $\mathrm{Ca}^{2+}$ ions. They are unique ion channels, which influence cell death rates and cell survival (39). Some channels are constitutively open, whereas others are activated by $\mathrm{Ca}^{2+}{ }_{i}$ overload $(31,32)$. TRPM2 is widely expressed in many cell types, including brain, heart, and endothelial cells $(11,40)$. Li et al. reported that TRPM2 channels were activated in response to oxidative stress, which could be initiated by pharmacological stimuli (12). Hoffman et al. showed that the modulation of $\mathrm{Ca}^{+2}$ entry via TRPM2 channels was important for maintaining mitochondrial function and reducing ROS levels in cardiomyocytes (41). Other studies demonstrated that TRPM2 channels were involved in myocardial ischemia-reperfusion injury $(42,43)$. In these studies, the authors suggested that TRPM2 channels were mainly associated with $\mathrm{Ca}^{2+}$ overload, mitochondrial dysfunction, and the apoptosis signaling pathway (42, 43).

In the present study, TRPM2 channels were present in cardiomyocytes, and they were stimulated by cumene hydroperoxide and blocked by antranilic acid, respectively. Moreover PAC increased oxidative stress, $\mathrm{Ca}^{2+}$ influx, and apoptosis in cardiomyocytes. NAC reduced the effectiveness of oxidative stress-sensitive TRPM2 channels in cardiomyocytes due to its antioxidant property.

Previous research demonstrated a close relationship between heart failure and oxidative stress. ROS-induced changes in heart failure included myocardial hypertrophy, fibrosis, and apoptosis (44). When ROS production exceeded the capacity of control mechanisms, including superoxide dismutase, glutathione, and catalase, it damaged mitochondrial components and initiated apoptosis in the heart (45). As the major role of ROS in this pathology is well known, free radical scavengers, such as NAC, may be able to reduce this damage. Neri et al. showed protective effects of NAC on postprandial oxidative stress and endothelial dysfunction in patients with untreated type 2 diabetes mellitus (46).

Although the importance of oxidative stress and antioxidant therapy in chemotherapy-induced cardiotoxicity is well known, its role in the modulation of TRPM2 channels has not been evaluated in cardiomyocytes before. Understanding the molecular mechanisms of chemotherapy-induced cardiotoxicity is necessary to improve preventive strategies. To the best of our knowledge, no previous studies have examined the effect of a combination of PAC and NAC on oxidative stress, apoptosis, and $\mathrm{Ca}^{2+}$ entry through TRPM2 channels in cardiomyocytes. The present study indicated that NAC modulated PAC-induced oxidative stress and apoptosis through regulation of TRPM2 channels. Furthermore, NAC suppressed mitochondrial depolarization levels and provided protection against the rate of programmed cell death, as determined by caspase 3 and caspase 9 measurements.
Oxidative stress is associated with oxidative damage, which leads to $\mathrm{Ca}^{2+}$ influx into cells through TRPM2 channels. ROS, such as hydrogen peroxide, can affect the functions of several proteins and TRPM2 channels by oxidation of cysteine residues (47). These damaging effects of ROS on TRPM2 channels could be controlled by endogenous antioxidants, such as reduced glutathione (GSH). NAC is a sulphydryl donor, with a free thiol group, which enhances glutathione antioxidant capacity. NAC is hydrolyzed to cysteine in cells, thereby stimulating GSH synthesis. By this mechanism, NAC can prevent GSH depletion in cells. (48). Previous studies reported that an increase in glutathione peroxidase activity was cardioprotective against left ventricular remodeling and failure after a myocardial infarction $(49,50)$. Özgül et al. showed an activator role of GSH depletion on $\mathrm{Ca}^{2+}$ entry through TRPM2 channels in dorsal root ganglions and demonstrated protective properties of NAC on $\mathrm{Ca}^{2+}$ entry through regulation of these channels (13).

In conclusion, the results showed that PAC can induce apoptosis and oxidative stress and result in increased $\mathrm{Ca}^{2+}{ }_{\mathrm{i}}$ levels in cardiomyocytes. In addition, NAC showed protective effects against PAC-induced cardiotoxicity through modulation of TRPM2 channels. Given the absence of an effective treatment for chemotherapy-induced cardiotoxicity, understanding of the underlying pathophysiological mechanism of cardiotoxicity and potential therapeutic targets are important in patients treated with chemotherapeutic agents.

\section{Conflict of interest}

No conflict of interest was declared by the authors.

\section{REFERENCES}

1. Angsutararux $P$, Luanpitpong $S$, Issaragrisil S. Chemotherapy-Induced Cardiotoxicity: Overview of the Roles of Oxidative Stress. Oxid Med Cell Longev 2015; 2015: 795602.

2. Pai VB, Nahata MC. Cardiotoxicity of chemotherapeutic agents: incidence, treatment and prevention. Drug Saf 2000; 22: 263-302.

3. Rowinsky EK, Donehower RC. Paclitaxel (taxol). N Engl J Med 1995; 332: 1004-14.

4. Curigliano G, Mayer EL, Burstein HJ, Winer EP, Goldhirsch A. Cardiac toxicity from systemic cancer therapy: a comprehensive review. Prog Cardiovasc Dis 2010; 53: 94-104.

5. Schimmel KJ, Richel DJ, van den Brink RB, Guchelaar HJ. Cardiotoxicity of cytotoxic drugs. Cancer Treat Rev 2004; 30: 181-91.

6. Boehmerle W, Splittgerber U, Lazarus MB, McKenzie KM, Johnston DG, Austin DJ, et al. Paclitaxel induces calcium oscillations via an inositol 1,4,5trisphosphate receptor and neuronal calcium sensor 1-dependent mechanism. Proc Natl Acad Sci U S A 2006; 103: 18356-61.

7. Meshkini A, Yazdanparast R. Involvement of oxidative stress in taxolinduced apoptosis in chronic myelogenous leukemia K562 cells. Exp Toxicol Pathol 2012; 64: 357-65.

8. Nagoor Meeran MF, Mainzen Prince PS. Protective effects of Nacetylcysteine on lipid peroxide metabolism on isoproterenol-induced myocardialinfarcted rats. J Biochem Mol Toxicol 2011; 25: 151-7.

9. Arica V, Demir IH, Tutanc M, Basarslan F, Arica S, Karcioglu M, et al. NAcetylcysteine prevents doxorubucin-induced cardiotoxicity in rats. Hum Exp Toxicol 2013; 32: 655-61.

10. Mansour HH, El Kiki SM, Hasan HF. Protective effect of $\mathrm{N}$-acetylcysteine on cyclophosphamide-induced cardiotoxicity in rats. Environ Toxicol Pharmacol 2015; 40: 417-22.

11. Zhan KY, Yu PL, Liu CH, Luo JH, Yang W. Detrimental or beneficial: the role of TRPM2 in ischemia/reperfusion injury. Acta Pharmacol Sin 2016; 37: 4-12. 12. Li J, Gao Y, Bao X, Li F, Yao W, Feng Z, et al. TRPM2: a potential drug target to retard oxidative stress. Front Biosci (Landmark Ed) 2017; 22: 1427-38.

13. Özgül C, Nazıroğlu M. TRPM2 channel protective properties of $N$ acetylcysteine on cytosolic glutathione depletion dependent oxidative stress and $\mathrm{Ca}^{2+}$ influx in rat dorsal root ganglion. Physiol Behav 2012; 106: 122-8.

14. Pan Z, Gollahon L. Taxol directly induces endoplasmic reticulum-associated calcium changes that promote apoptosis in breast cancer cells. Breast J 2011; 17: $56-70$.

15. Hung JH, Wee SK, Omar HA, Su CH, Chen HY, Chen PS, et al. Nuclear factor erythroid-2-related factor regulates LRWD1 expression and cellular adaptation to oxidative stress in human embryonal carcinoma cells. Biochimie 2018; 148: 99-106.

16. Martinez NA, Ayala AM, Martinez M, Martinez-Rivera FJ, Miranda JD, Silva WI. Caveolin-1 Regulates the P2Y2 Receptor Signaling in Human 1321N1 Astrocytoma Cells. J Biol Chem 2016; 291: 12208-22. 
17. Uğuz AC, Naziroğlu M, Espino J, Bejarano I, González D, Rodríguez AB, et al. Selenium modulates oxidative stress-induced cell apoptosis in human myeloid HL-60 cells through regulation of calcium release and caspase- 3 and 9 activities. J Membr Biol 2009; 232: 15-23.

18. Espino J, Pariente JA, Rodríguez AB. Role of melatonin on diabetes-related metabolic disorders. World J Diabetes 2011; 2: 82 - 91.

19. Özdemir ÜS, Nazıroğlu M, Şenol N, Ghazizadeh V. Hypericum perforatum attenuates spinal cord injury-induced oxidative stress and apoptosis in the dorsal root ganglion of rats:involvement of TRPM2 and TRPV1 channels. Mol Neurobiol 2015; 23: 1-12.

20. Bejarano I, Redondo PC, Espino J, Rosado JA, Paredes SD, Barriga C, et al. Melatonin induces mitochondrial-mediated apoptosis in human myeloid HL60 cells. J Pineal Res 2009; 46: 392 - 400.

21. Espino J, Bejarano I, Redondo PC, Rosado JA, Barriga C, Reiter RJ, et al. Melatonin reduces apoptosis induced by calcium signaling in human leukocytes: Evidence for the involvement of mitochondria and Bax activation. J Membr Biol 2010; 233: 105-18.

22. Öz A, Çelik Ö. Curcumin inhibits oxidative stress-induced TRPM2 channel activation, calcium ion entry and apoptosis values in SH-SY5Y neuroblastoma cells: Involvement of transfection procedure. Mol Membr Biol 2016; 33: 7688.

23. Uguz AC, Cig B, Espino J, Bejarano I, Naziroglu M, Rodríguez AB, et al. Melatonin potentiates chemotherapy-induced cytotoxicity and apoptosis in rat pancreatic tumor cells. J Pineal Res 2012; 53: 91-8.

24. Övey IS, Naziroğlu M. Homocysteine and cytosolic GSH depletion induce apoptosis and oxidative toxicity through cytosolic calcium overload in the hippocampus of aged mice: involvement of TRPM2 and TRPV1 channels. Neuroscience 2015; 284: 225-33.

25. Magdy T, Burmeister BT, Burridge PW. Validating the pharmacogenomics of chemotherapy-induced cardiotoxicity: What is missing? Pharmacol Ther 2016; 168: 113-125.

26. Bonita R, Pradhan R. Cardiovascular toxicities of cancer chemotherapy. Semin Oncol 2013; 40: 156-67.

27. Giordano SH, Booser DJ, Murray JL, Ibrahim NK, Rahman ZU, Valero V, et al. A detailed evaluation of cardiac toxicity: a phase II study of doxorubicin and one or three hour infusion paclitaxel in patients with metastatic breast cancer. Clin Cancer Res. 2002; 8: 3360-8.

28. Wouters KA, Kremer LC, Miller TL, Herman EH, Lipshultz SE. Protecting against anthracycline-induced myocardial damage: a review of the most promising strategies. Br J Haematol 2005; 131: 561-78.

29. Minotti G, Cairo G, Monti E. Role of iron in anthracycline cardiotoxicity: new tunes for an old song? FASEB J 1999; 13: 199-212.

30. Galley HF, McCormick B, Wilson KL, Lowes DA, Colvin L, Torsney C. Melatonin limits paclitaxel-induced mitochondrial dysfunction in vitro and protects against paclitaxel-induced neuropathic pain in the rat. J Pineal Res 2017; 63(4). doi: 10.1111/jpi.12444. Epub 2017 Sep 22.

31. Varga ZV, Ferdinandy $P$, Liaudet $L$, Pacher P. Drug-induced mitochondrial dysfunction and cardiotoxicity. Am J Physiol Heart Circ Physiol 2015; 309: H1453-67.

32. Santulli G, Xie W, Reiken SR, Marks AR. Mitochondrial calcium overload is a key determinant in heart failure. Proc Natl Acad Sci U S A 2015; 112: 1138994.
33. Hajnóczky G, Robb-Gaspers LD, Seitz MB, Thomas AP. Decoding of cytosolic calcium oscillations in the mitochondria. Cell 1995; 82: 415-24.

34. Hansford RG. Physiological role of mitochondrial $\mathrm{Ca}^{2+}$ transport. J Bioenerg Biomembr 1994; 26: 495-508.

35. Görlach A, Bertram K, Hudecova S, Krizanova O. Calcium and ROS: A mutual interplay. Redox Biol 2015; 6: 260-71.

36. Kidd JF, Pilkington MF, Schell MJ, Fogarty KE, Skepper JN, Taylor CW, et al. Paclitaxel affects cytosolic calcium signals by opening the mitochondrial permeability transition pore. J Biol Chem 2002; 277: 6504-10.

37. Berridge MJ, Bootman MD, Roderick HL. Calcium signalling: dynamics, homeostasis and remodelling. Nat Rev Mol Cell Biol 2003; 4: 517 - 29.

38. Flemming NB, Gallo LA, Forbes JM. Mitochondrial Dysfunction and Signaling in Diabetic Kidney Disease: Oxidative Stress and Beyond. Semin Nephrol 2018; 38: 101- 10.

39. Miller KD, Chap LI, Holmes FA, et al. Randomized phase III trial of capecitabine compared with bevacizumab plus capecitabine in patients with previously treated metastatic breast cancer. J Clin Oncol 2005; 23: 792 - 9. 40. McHugh D, Flemming $R$, Xu SZ, Perraud AL, Beech DJ. Critical intracellular $\mathrm{Ca}^{2+}$ dependence of transient receptor potential melastatin 2 (TRPM2) cation channel activation. J Biol Chem 2003; 278: 11002-6.

41. Hoffman NE, Miller BA, Wang J, Elrod JW, Rajan S, Gao E, et al. Ca ${ }^{2+}$ entry via Trpm2 is essential for cardiac myocyte bioenergetics maintenance. Am Physiol Heart Circ Physiol 2015; 308: H637-50.

42. Yang KT, Chang WL, Yang PC, Chien CL, Lai MS, Su MJ, et al. Activation of the transient receptor potential $\mathrm{M} 2$ channel and poly(ADP-ribose) polymerase is involved in oxidative stress-induced cardiomyocyte death. Cell Death Differ 2006; 13: 1815-26.

43. Roberge S, Roussel J, Andersson DC, Meli AC, Vidal B, Blandel F, et al. TNFalpha-mediated caspase-8 activation induces ROS production and TRPM2 activation in adult ventricular myocytes. Cardiovasc Res 2014; 103: 90-9.

44. Ho QT, Kuo CJ. Vascular endothelial growth factor: biology and therapeutic applications. Int J Biochem Cell Biol 2007; 39: 1349 - 57.

45. Lattanzio FA Jr, Tiangco D, Osgood C, Beebe S, Kerry J, Hargrave BY Cocaine increases intracellular calcium and reactive oxygen species, depolarizes mitochondria, and activates genes associated with heart failure and remodeling. Cardiovasc Toxicol 2005 Fall; 5: 377-90.

46. Neri S, Calvagno S, Mauceri B, Misseri M, Tsami A, Vecchio C, et al. Effects of antioxidants on postprandial oxidative stress and endothelial dysfunction in subjects with impaired glucose tolerance and type 2 diabetes. Eur J Nutr 2010; 49: 409-16.

47. Hecquet $\mathrm{CM}$, Ahmmed GU, Vogel SM, Malik AB. Role of TRPM2 channel in mediating $\mathrm{H}_{2} \mathrm{O}_{2}$-induced $\mathrm{Ca}^{2+}$ entry and endothelial hyperpermeability. Circ Res 2008; 102: 347-55.

48. Talasaz AH, Khalili H, Fahimi F, Jenab Y, Broumand MA, Salarifar M, et al. Effects of $\mathrm{N}$-acetylcysteine on the cardiac remodeling biomarkers and major adverse events following acute myocardial infarction: a randomized clinica trial. Am J Cardiovasc Drugs 2014; 14: 51-61.

49. Shiomi T, Tsutsui $H$, Matsusaka $H$, Murakami K, Hayashidani S, Ikeuchi M et al. Overexpression of glutathione peroxidase prevents left ventricular remodeling and failure after myocardial infarction in mice. Circulation 2004; 109: 544-9.

50. Sochman J. N-acetyl cysteine in acute cardiology: 10 years later: what do we know and what would we like to know?! J Am Coll Cardiol 2002; 39 : 1422 